\title{
Site Classification and Analysis in Beijing Based on Geological Factors
}

\author{
Jiajun Sun ${ }^{1}$, Yongqi Meng ${ }^{1}$, Shuai zhao ${ }^{1}$, Zhanfei $\operatorname{Li}^{1}$, Xiaodi Tan ${ }^{1}$ \\ ${ }^{1}$ Beijing Earthquake Administration, 28 Suzhou Street, Haidian District, Beijing, China
}

\begin{abstract}
The paper involves the application of the surface geological method for regional site classification in Beijing. Geological maps are collected through GIS to create a relationship of classification between the geological factors of the geological maps and the site classification index of the US NEHRP code. First, the site classification of the US NEHRP is obtained, and based on the relationship of conversion, given by Chinese researchers, between the site classification of the US NEHRP and the China's Code for Seismic Design of Buildings (GB50011-2010), the results of the site classification of Beijing are obtained based on China's Code (GB50011-2010). Finally, based on the collected borehole data in Beijing, the results of the site classification map are verified and analyzed.
\end{abstract}

\section{INTRODUCTION}

Over the past decades, by investigating damages of destructive earthquake researchers have found that under the same conditions the earthquake damage varies with different site types. The United States began to study the impact of site conditions on the damages of earthquake through San Francisco earthquake happened the 1906. When China studied the damages caused by Tangshan Earthquake in 1976, it found that different site conditions had different effects on the earthquake. Therefore, it is believed that the site type plays an important role in the damages caused by earthquake. The site classification according to site characteristics and the adoption of reasonable ground motion parameters to meet the needs of seismic design is important to research in engineering sites. As China's economy grows rapidly, the demands for site conditions have increased from a single area to a region. For example, what Beijing needs most is a city-wide or district-wide map of site classification. However, in China's Code for Seismic Design of Buildings (GB50011-2010), as the dual indicators of average shear wave velocity and overburden thickness are used to classify sites, it is difficult to obtain regional site classification simply by using China's site classification method. In America, Borcherdt, Wills, etc. first implemented regional site classification by using geological factors as classification indicators and carried out such classifications in the San Francisco Bay Area and California. In China's Taiwan, Li Xiti classified sites in Taiwan by adopting geological maps. Therefore, the classification method of geological factors is ideal for regional site classification. In the paper, this classification method is used to classify the sites in Beijing, to obtain the site classification results applicable to the China's Code (GB50011-2010), and to analyze the results by collecting borehole data in the engineering sites.

\section{SITE CLASSIFICATION BASED ON GEOLOGICAL FACTORS}

The method of site classification based on geological factors is to classify geological factors through regional geological maps, and to create a corresponding relationship of connection between the geological factors and site classification indicators. Based on this relationship, the regional site classification can be obtained. As the basic geological data of geological maps and geomorphological maps are easy to obtain, many scholars conduct research on regional site conditions by creating the relationship between the age and lithology of rock formations and site classification indicators.In this paper, a digital geological map with a scale of 1:2.5 million was used. It, as a database management system based on GIS, is developed by the China Geological Survey and uses geological methods, achievements, as well as GIS technology.

In order to discuss the site classification method based on geological origin, site classification method of the US NEHRP was adopted in this paper to classify the sites in Beijing through a digital geological map with a scale of 1:2.5 million. The descriptions of NEHRP site classification is shown in Table 1. 
Table 1 Descriptions of NEHRP Site Classification

\begin{tabular}{|c|c|c|}
\hline $\begin{array}{l}\text { Site } \\
\text { Classification }\end{array}$ & $\begin{array}{l}\text { General } \\
\text { Description }\end{array}$ & Index \\
\hline $\mathrm{A}$ & Hard bedrock & $\mathrm{Vs}_{30}>1500 \mathrm{~m} / \mathrm{s}$ \\
\hline $\mathrm{B}$ & Rock & $1500 \mathrm{~m} / \mathrm{s}>V_{\mathrm{s}} 30>760 \mathrm{~m} / \mathrm{s}$ \\
\hline $\mathrm{C}$ & $\begin{array}{l}\text { Hard soil, } \\
\text { mostly gravel, } \\
\text { standard soft } \\
\text { rock }\end{array}$ & $\begin{array}{l}760 \mathrm{~m} / \mathrm{s}>\mathrm{Vs}_{30}>360 \mathrm{~m} / \mathrm{s}, \text { or } \\
\mathrm{N}>50, \quad \mathrm{su}_{\mathrm{u}}>100 \mathrm{Kpa}\end{array}$ \\
\hline $\mathrm{D}$ & $\begin{array}{l}\text { Hard soil (sand, } \\
\text { clay and gravel) }\end{array}$ & $\begin{array}{l}360 \mathrm{~m} / \mathrm{s}>\mathrm{Vs}_{30}>180 \mathrm{~m} / \mathrm{s}, \text { or } \\
50>\mathrm{N}>15, \\
100>_{\mathrm{S}_{\mathrm{u}}}>50 \mathrm{Kpa}\end{array}$ \\
\hline $\mathrm{E}$ & $\begin{array}{l}\text { Soft clay with } \\
\text { thickness } H \text { in } \\
\text { soil section }\end{array}$ & $\begin{array}{l}\mathrm{V}_{\mathrm{s} 30}<180 \mathrm{~m} / \mathrm{s} \text {, or soft dry } \\
\text { soil with } \mathrm{H}>3 \mathrm{~m} \\
(\mathrm{PI}>20, \mathrm{w}>40 \% \text {, } \\
\left.\mathrm{Su}_{\mathrm{u}}<25 \mathrm{Kpa}\right)\end{array}$ \\
\hline $\mathrm{F}$ & $\begin{array}{l}\text { Highly sensitive } \\
\text { clay that is easy } \\
\text { to collapse or } \\
\text { damage by } \\
\text { earthquake, and } \\
\text { soil with poor } \\
\text { cohesion; } \\
\text { Mudstone or } \\
\text { clay of high } \\
\text { organic matter; } \\
\text { Very plastic } \\
\text { clay; very thick } \\
\text { clay with soft- } \\
\text { medium } \\
\text { stiffness }\end{array}$ & $\mathrm{H}>8 \mathrm{~m}, \quad$ and $\mathrm{PI}>75$ \\
\hline
\end{tabular}

In the table, Vs30 represents the average shear wave velocity within $30 \mathrm{~m}$ below the ground surface; $\mathrm{N}$ is the value of standard penetration; su is the undrained shear strength; $\mathrm{w}$ is the humidity percentage; $\mathrm{H}$ represents the thickness of the covering soil, while PI is the plasticity index.

The elements of the geological maps of the Beijing area were sorted out according to age and soil lithology, and then based on the classification and definition of NEHRP site types and the characteristics of classifying geological age in China, the geological bodies in the geological map were classified according to the following ideas:

(1)During or before Mesozoic (Mz)

The soil layers and rock layers during or before Mesozoic $(\mathrm{Mz})$ are bedrock with higher hardness, so they all belong to type A except for the weathered type B.

(2)After the Mesozoic (Mz) and during the Cenozoic Erathem

Due to the complex distribution of lithology and soil layer, the geological maps of this part were arranged in chronological order as follows: Eogene (E), Neogene (N) and Quaternary (Q) system, of which Quaternary (Q) was subdivided into $\mathrm{Qp}$ and $\mathrm{Qh}$. After the age and geological descriptions of the geological maps were sorted out in this part, they were matched to the NEHRP classification one by one, which created corresponding connections. The corresponding NEHRP classification results are shown in Table 2.

Table 2 Relationship between Geological Conditions and Index of NEHRP Site Classification (partial)

\begin{tabular}{|c|c|c|c|}
\hline $\begin{array}{c}\text { Geological } \\
\text { description/era }\end{array}$ & $\begin{array}{c}\text { Holocene } \\
\text { Series }\end{array}$ & $\begin{array}{c}\text { Pleistocene } \\
\text { Series }\end{array}$ & $\begin{array}{c}\text { Neogene } \\
\text { System }\end{array}$ \\
\hline $\begin{array}{c}\text { Eolian deposit, } \\
\text { aeolian sand }\end{array}$ & $\mathrm{E}$ & $\mathrm{E}$ & $\mathrm{E}$ \\
\hline $\begin{array}{c}\text { River, lake and } \\
\text { marsh deposits }\end{array}$ & $\mathrm{E}$ & $\mathrm{DE}$ & $\mathrm{DE}$ \\
\hline Alluvium & $\mathrm{CD}$ & $\mathrm{D}$ & $\mathrm{D}$ \\
\hline $\begin{array}{c}\text { Glacier } \\
\text { accumulation }\end{array}$ & $\mathrm{CD}$ & $\mathrm{CD}$ & $\mathrm{D}$ \\
\hline Tephra & $\mathrm{B}$ & $\mathrm{B}$ & $\mathrm{B}$ \\
\hline
\end{tabular}

Table 3 Comparison of Chinese and American Site Classification Index

\begin{tabular}{|c|c|c|}
\hline China & NEHRP(US) & Vs(m/s) \\
\hline IV & E & 190 \\
\hline \multirow{2}{*}{ III } & DE & 250 \\
& D & 300 \\
\hline \multirow{2}{*}{ II } & CD & 370 \\
& C & 450 \\
\hline I $_{1}$ & BC & 760 \\
\hline \multirow{2}{*}{ I $_{0}$} & B & 1000 \\
& A & 1500 \\
\hline
\end{tabular}

After the geological bodies in the geological maps were classified according to the NEHRP site classification, the preliminary results of the site type were obtained. Based on the relationship between the site classification of China and the United States given by Lv Hongshan et al., the corresponding relationship was given of site classification in Beijing in accordance with China's seismic design code. The site classification index between China and US is compared as shown in Table 3.

The data in the geological maps was classified on the GIS platform according to the site classification index that conforms to China's seismic design code, and the results were obtained of site classification with a scale of 1:2.5 million based on geological factors in Beijing, as shown in Figure 1. 


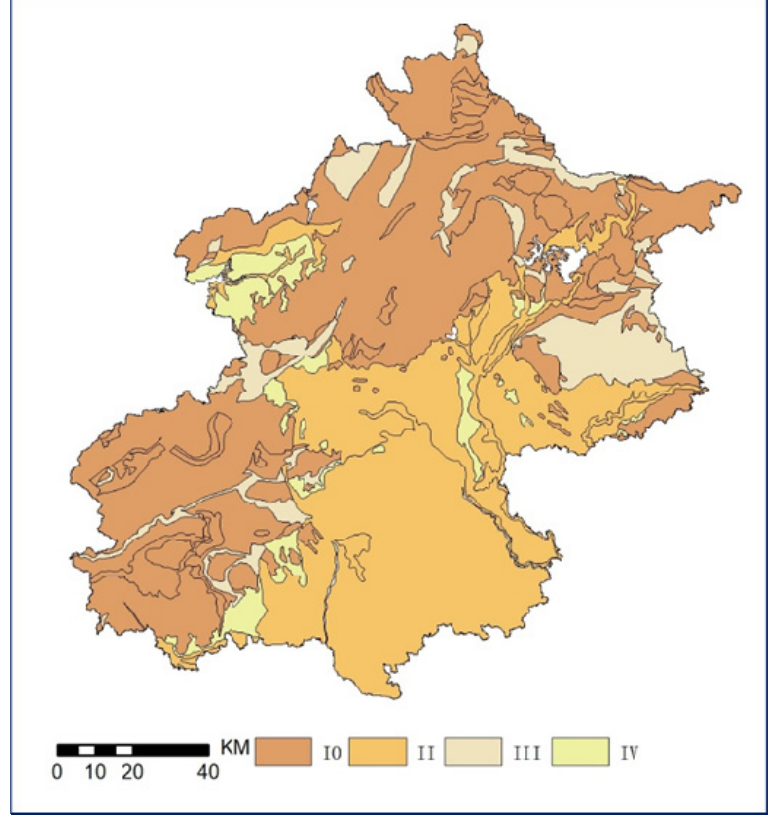

Figure 1 Regional Site Classification in Beijing

\section{COMPARATIVE VERIFICATION BASED ON BOREHOLE DATA}

Data on 203 boreholes were collected for evaluations of seismic safety within the administrative scope of Beijing, and the equivalent shear wave velocity of the soil layer was calculated. The sites of these boreholes were classified according to the classification standard given in China's Code for Seismic Design of Buildings (GB50011-2010). Then a point layer was generated through the GIS software to register and superimpose the dot map and the site classification map. The Roman numerals near the drilling points indicate the results of site classification, as shown in Figure 2.

\section{RESULTS AND ANALYSIS}

The results were compared of site classification of boreholes, in Beijing, reflected in Figure 2 with that based on geological factors, the main reasons for the difference are as follows:

1.The northern and western parts of Beijing are mountainous areas, and most boreholes in that areas locate in platforms on both sides of the river. Therefore, the site classification of those areas with boreholes is mostly sedimentary or non-bedrock areas. In the bedrock area, there is little borehole data because of few human activities. From a geological point of view, the classification based on geological maps illustrates the situation of mountain sites.

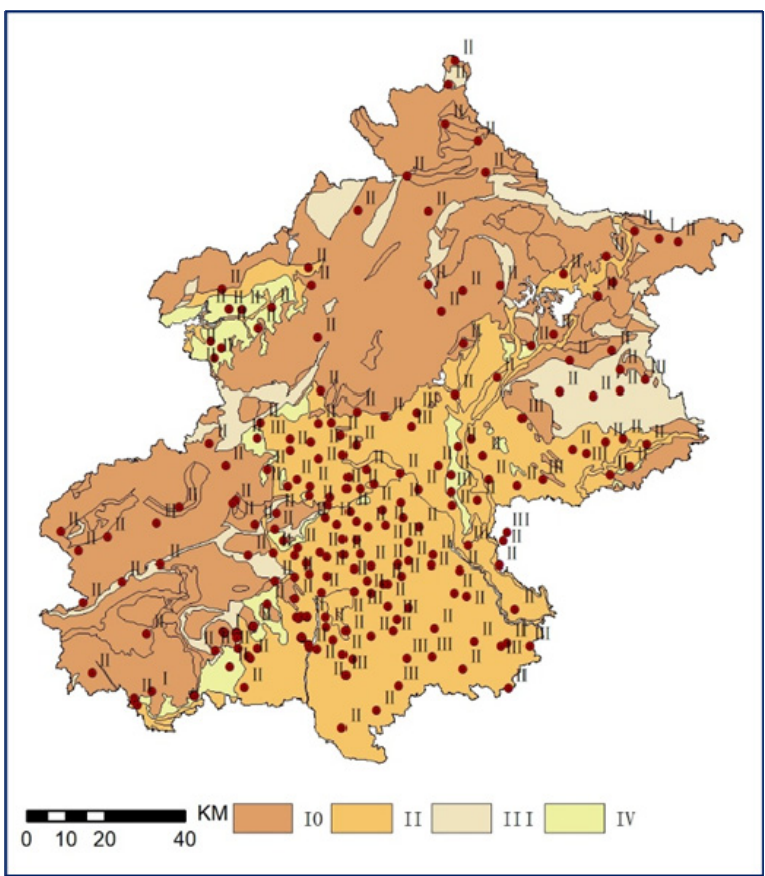

Figure 2 The Superimposition of the Dot Map of Boreholes and the Map of Site Classification Map

2. The geological map used in this paper is the one with a scale of 1:2.5 million. The results of site classification reflect the situation of the sites in Beijing, but the lack of higher-precision classification of geological bodies in the mountainous areas leads to the inconsistency in the results of the two classification methods. If geological maps and geomorphologic maps with higher accuracy are adopted, the characteristics of sites in Beijing can be more accurately reflected.

3. The site classification based on the geological maps reflects the basic regional situation, but the measured borehole data in the later stage are needed to draw more accurate conclusions of the results of site classification. In addition, due to the complicated Quaternary sediments in the plain area in Beijing, it is also difficult to divide the plain area according to the geological maps. If the geomorphological maps as well as other maps that illustrate the regional site conditions are combined to classify the site types, the basis and standards will be clear for the classification of site types in the plain area in Beijing.

\section{FUND PROJECTS:}

Supported by the Youth Fund of Beijing Earthquake Administration.

\section{ABOUT THE AUTHOR:}

Jiajun Sun, mainly engaged in quaternary geological research,

\section{REFERENCES}

1. State Bureau of Technical Supervision, Ministry of Construction of the People's Republic of China. 
Code for seismic design of buildings (GBJ 11-89)

[S] . Beijing: China Construction Industry Press, 1989.

2. Ministry of Construction of the People's Republic of China, National Quality Supervision, Inspection and Quarantine Bureau. Code for seismic design of buildings (GB50011-2001) [S ] . Beijing: China Construction Industry Press, 2001.

3. Ministry of Housing and Urban-Rural Development of the People's Republic of China, General Administration of Quality Supervision, Inspection and Quarantine of the People's Republic of China. Code for seismic design of buildings (GB500112010) [S]. Beijing: China Construction Industry Press, 2010.

4. Lee C T, Tsai B R. Mapping vS (30) in Taiwan[J]. Terr Atmos Ocean, 2008, 19(6): 671-682.

5. Wills,C. J.A Site Conditions Map for California Based on Geology and Shear Wave Velocity[J].Bull Seism Soc Am.2000,90(6B):187-208.

6. MATSUOKA $\mathrm{M}$, WAKAMATSU $\mathrm{K}$, FUJIMOTO K, et al A Average shear wave velocity mapping using Japan engineering geomorphologic classification map $[\mathrm{J}]$. Doboku Gakkai Ronbunshu, 2006, 23( 1):57S-68S .

7. KAZUO FUJIMOTO, SABUROH MIDORIKAWA . Prediction of average shear wave velocity for ground shaking mapping using the digital national land information of Japan[C] //The 3th World Conference on Earthquake Engineering . VancouVer, B . C, Canada, 2004 .

8. D J, Allen T I . Topographic slope as a proxy for seismic site conditions and amplification [ J ] . Bulletin of the Seismological Society America, 2007, 97:1379-1395.

9. Kun Chen, Yanxiang Yu, Mengtan Gao. Study on the Shake Map system considering site effects[J].Earthquake Research in China, 2010,26(1):92-102.

10. Kun Chen, Yanxiang Yu. Seismic map of the Yushu Qinghai earthquake on April 14, 2010[J].Earthquake Research in China,2011, 27(1):99-102.

11. BORCHERDT R D.Estimates of Site-dependent Response Spectra for Design(Methodology and Justification) [ $\mathrm{J}$ ] . Earth-quake Spectra, 1994,10(4):617-653.

12. Dacheng Shi, Ruizhi Wen. Estimation method of Vs30 and peak acceleration amplification factor for regional sites. Earthquake Engineering and Engineering Vibration. 2012, 32(4):106-112.

13. Jing Li, Chao Zhang, Dehai Zhu, et al. Research on the zoning of landform types in Beijing based on space technology. China Agricultural Science and Technology Review. 2007,9(2):126-129. 